\title{
Production of Light Weight Foam Concrete with Sustainable Materials
}

\author{
Anowar Wakaa Ali \\ Department of Civil Engineering \\ College of Engineering \\ University of Baghdad \\ Baghdad, Iraq \\ a.ali1901m@coeng.uobghdad.edu.iq
}

\author{
Nada Mahdi Fawzi \\ Department of Civil Engineering \\ College of Engineering \\ University of Baghdad \\ Baghdad, Iraq \\ nada.aljalawi@coeng.uobaghdad.edu.iq
}

\begin{abstract}
Most of the recent works related to the construction industry in Iraq are focused on investigating the validity of local raw materials as alternatives to the imported materials necessary for some practical applications, especially in thermal and sound insulation. This investigation includes the use of limestone dust as partial substitution of cement in combination with foam agent and silica fume to produce sustainable Lightweight Foam Concrete (LWFC). This study consists of two stages. In the first stage, trial mixes were performed to find the optimum dosage of foam agent. Limestone dust was used as a partial replacement for cement. Chemical analysis and fineness showed great similarity with cement. Many concrete mixes were prepared with the content of lime dust powder being $10 \%, 14 \%$, and $18 \%$ as partial replacement of cement by weight. The results indicate that the compressive strength at 7,28 , and 90 days of age was increased for specimens with $14 \%$ limestone dust. The best results in compressive strength show an increase at 7 days and a decrease at 28 and 90 days for concrete specimens with $14 \%$ limestone dust. In addition, the results show a decrease in dry density for concrete containing $14 \%$ lime dust. In the second stage, different percentages of Polypropylene Fibers were added to the concrete, all mixes, containing a constant content of limestone dust of $14 \%$ by weight of cement, were modified using different percentages of Polypropylene Fibers $(1 \%, 1.5 \%$, and $2 \%$ by volume) and the best percentage was found to be $1 \%$. The addition of Polypropylene Fibers enhances splitting tensile and flexural strength at 28 days by $14.55 \%$ and $55 \%$ respectively.
\end{abstract}

Keywords-lightweight concrete; foam concrete; sustainable materials; polypropylene fibers, ;imestone dust

\section{INTRODUCTION}

One of the disadvantages of conventional concrete is its high self- weight. The density of normal concrete is in the order of 2200 to $2600 \mathrm{~kg} / \mathrm{m}^{3}$. This heavy self-weight makes it, to some extent, an uneconomical structural material. Attempts have been made in the past to reduce the self-weight of concrete in order to increase its efficiency. Light-Weight Concrete (LWC) is a concrete whose density varies from 300 to $1850 \mathrm{~kg} / \mathrm{m}^{3}$ [1]. There are many advantages of having low density. It helps in the reduction of dead load, increases the progress of building, and lowers haulage and handling costs. The weight of a building on the foundation is an important factor in design, particularly in the case of weak soil and tall structures. In framed structures, the beams and columns have to carry the load of floors and walls. If floors and walls are made of LWC, this will result in considerable cost decrease. Another important characteristic of LWC is its relatively low thermal conductivity, a property which improves with decreasing density. In extreme climatic conditions and in the case of buildings where air-conditioning is to be installed the use of LWC with low thermal conductivity will produce considerable advantages from the points of thermal comfort and lower power consumption [2]. On the other hand, the cost of natural resources is increasing constantly, leading to the search for alternatives, such as recycled materials like rice husk ash, sawdust ash [3], silica fume, fly ash, coal bottom ash, limestone dust, marble powder, tile powder, millet husk ash, crumb rubber, etc. Also, ordinary Portland Cement (OPC), has been related to several diseases [4-5].

Basically, there are three methods for making LWC. The first way is by using porous lightweight aggregates of low apparent specific gravity. This type of concrete is known as lightweight aggregate concrete. The second way is by introducing large voids within the concrete or mortar mass. These voids should be clearly distinguished from the extremely fine voids produced by air entrainment. This type of concrete is variously knows as aerated, cellular, foamed, or gas concrete. Thirdly, by omitting the fine aggregates from the mix in such a way that a large number of interstitial voids are present. Normal-weight coarse aggregates are generally used. This concrete is called no-fines concrete [2]. Based on the purpose of use, there are three types of concrete. The first type is known as Non-Structural LWC. This is employed mainly for insulation purposes. With low unit weight, seldom exceeding $800 \mathrm{~kg} / \mathrm{m}^{3}$, its heat insulation value is high and compressive strength is low, from 0.69 to $6.89 \mathrm{~N} / \mathrm{mm}^{2}$ [6]. The second type is Moderate Strength LWC. The use of this concrete requires a fair degree of compressive strength, and thus they fall about midway between the structural and low density concrete. This is sometimes designed as "fill" concrete. Compressive strength varies approximately from 6.89 to $17.24 \mathrm{~N} / \mathrm{mm}^{2}$, the insulation values are intermediate, and its density is between 800 to $1300 \mathrm{~kg} / \mathrm{m}^{3}$ [7]. The third type is known as Structural LWC. This type can be defined as a concrete with full structural efficiency containing aggregates which fall on the other end of 
the scale. Its minimum compressive strength is $17.24 \mathrm{~N} / \mathrm{mm}^{2}$ [8]. Most of structural LWCs are capable to produce concrete with excessive compressive strength. However, thermal insulation values for structural LWC are substantially better than NWC's. Since the unit weight of structural LWC is considerably greater than that of low density concrete, the insulation efficiency is lower [9]. The compressive strength of insulating LWC increases with increasing density and watercement ratio [10]. As for polypropylene fibers, research has shown that they increase concrete's resistance to impact loads [11].

\section{MATERIALS AND MIX PROPORTIONS}

\section{A. Cement}

OPC type I, manufactured by Al Kubaisa Cement Factory, was used in 3.1.1 cement in all the mixes throughout this investigation. The chemical and physical properties of this cement are presented in Tables I and II respectively. The test results indicate that the adopted cement, type $\mathrm{N} 42.5 \mathrm{MPa}$ conforms to the Iraqi specification No. 5/2019 [12].

TABLE I. CHEMICAL COMPOSITION OF CEMENT

\begin{tabular}{|c|c|c|}
\hline Oxide composition & Result & Limits of [12] \\
\hline Lime $(\mathrm{CaO})$ & 62 & - \\
\hline Silica $\left(\mathrm{SiO}_{2}\right)$ & 20.1 & - \\
\hline Alumina $\left(\mathrm{Al}_{2} \mathrm{O}_{3}\right)$ & 4.24 & - \\
\hline Iron oxide $\left(\mathrm{Fe}_{2} \mathrm{O}_{3}\right)$ & 4.16 & - \\
\hline Sulfate $\left(\mathrm{SO}_{3}\right)$ & 2.15 & $\begin{array}{l}\leq 2.8 \% \text { if } \mathrm{C}_{3} \mathrm{~A}>3.5 \\
\leq 2.5 \% \text { if } \mathrm{C}_{3} \mathrm{~A}<3.5\end{array}$ \\
\hline Magnesia (MgO) & 3.65 & $\leq 5 \%$ \\
\hline Loss on ignition (LOI.) & 3.42 & $\leq 4 \%$ \\
\hline Insoluble residue (IR) & 0.71 & $\leq 1.5 \%$ \\
\hline \multicolumn{3}{|c|}{ Main compounds (Bogues eq.) of cement } \\
\hline \multicolumn{2}{|c|}{ Tricalcium silicate $\left(\mathrm{C}_{3} \mathrm{~S}\right)$} & 59.02 \\
\hline \multicolumn{2}{|c|}{ Dicalcium silicate $\left(\mathrm{C}_{2} \mathrm{~S}\right)$} & 29.65 \\
\hline \multicolumn{2}{|c|}{ Tricalcium aluminate $\left(\mathrm{C}_{3} \mathrm{~A}\right)$} & 4.21 \\
\hline \multicolumn{2}{|c|}{ Tetracalcium aluminoferrite $\left(\mathrm{C}_{4} \mathrm{AF}\right)$} & 12.65 \\
\hline
\end{tabular}

TABLE II. PHYSICAL PROPERTIES OF CEMENT

\begin{tabular}{|c|c|c|}
\hline Physical properties & Test result & Limits of [12] \\
\hline $\begin{array}{c}\text { Specific surface area, Blaine } \\
\text { method, }\left(\mathrm{m}^{2} / \mathrm{kg}\right) .\end{array}$ & 295 & $\geq 250 \mathrm{~m}^{2} / \mathrm{kg}$ \\
\hline $\begin{array}{c}\text { Setting time } \\
\text {-Initial setting (min) } \\
\text {-Final setting (min) }\end{array}$ & $1: 38$ & $\begin{array}{c}\geq 45 \mathrm{~min} \\
\leq 600 \mathrm{~min}\end{array}$ \\
\hline $\begin{array}{c}\text { Compressive strength of } \\
\text { mortar (MPa) } \\
\text { 2-days }\end{array}$ & $3: 45$ & \\
28-days & 20.4 & $\geq 10 \mathrm{~N} / \mathrm{m}^{2}$ \\
$\geq 42.5 \mathrm{~N} / \mathrm{m}^{2}$ \\
\hline Soundness \% (autoclave) & 0.35 & $\leq 0.8$ \\
\hline
\end{tabular}

TABLE III. GRADING OF FINE AGGREGATES

\begin{tabular}{|c|c|c|}
\hline Sieve size (mm) & Passing \% of sand & Limits of [13] \\
\hline 10 & 100 & 100 \\
\hline 4.75 & 100 & $90-100$ \\
\hline 2.36 & 100 & $85-100$ \\
\hline 1.18 & 100 & $75-100$ \\
\hline 0.6 & 67.57 & $60-79$ \\
\hline 0.3 & 36.73 & $12-40$ \\
\hline 0.15 & 4.33 & $0-10$ \\
\hline
\end{tabular}

\section{B. Fine Aggregates}

Natural sand supplied from Al-Ekhadir quarry was used in the concrete mixes. The physical and chemical properties of fine aggregates are shown in Tables III and IV. The test results indicate that the sand grading is within the limits specified by the Iraqi Standard No. 45/1984 [13] and lies in Zone 4.

TABLE IV. PHYSICAL AND CHEMICAL PROPERTIES OF FINE AGGREGATES

\begin{tabular}{|c|c|c|}
\hline Properties of sand & Test results & Limits of [13] \\
\hline Fineness modulus & 2.16 & - \\
\hline Specific gravity & 2.61 & - \\
\hline Absorption & $0.8 \%$ & - \\
\hline $\mathrm{SO}_{3}$ & $0.23 \%$ & $\leq 0.5 \%$ \\
\hline Dry rodded density & $163.7 \mathrm{~kg} / \mathrm{m}^{3}$ & - \\
\hline Materials finer than $75 \mu \mathrm{m} \%$ & 2.6 & $\leq 5.0$ \\
\hline
\end{tabular}

\section{Foaming Agent}

Foaming agent for cellular concrete ASTM C796-97 [14] from Dr. Foamcrete was used to produce LWC by entraining a controlled amount of air bubbles to concrete mix. Table V indicates the technical description of the foaming agent used throughout this investigation.

TABLE V. TECHNICAL DESCRIPTION OF FOAMING AGENT (DATA TAKEN FROM MANUFACTURE PRODUCTION REPORT)

\begin{tabular}{|c|c|}
\hline Appearance & Liquid \\
\hline Color & Yellow \\
\hline Specific gravity & 1.1 \\
\hline Nitrate content & Nil \\
\hline Compatibility with cement & All types of Portland cement \\
\hline Point & Below $0^{\circ} \mathrm{C}$ \\
\hline Flash point & Water base \\
\hline LOI & 3.5 \\
\hline
\end{tabular}

\section{Mixing Water}

Water was used for mixing and curing of all concrete mixes conforming to standard Iraqi specification 1703 [15].

\section{E. Fibers}

Polypropylene fibers bought from Belgian Fibers Manufacturing were used for reinforcement. The specifications and properties of the fibers used throughout the experimental work are illustrated in Table VI according to the supplier.

TABLE VI. TECHNICAL PROPERTIES OF POLYPROPYLENE FIBERS

\begin{tabular}{|l|l|}
\hline Length of Fiber & $\mathbf{6 ~} \mathbf{~ m m}$ \\
\hline Diameter & $34 \mu \mathrm{m}$ \\
\hline Density & $0.91 \mathrm{gr} / \mathrm{cm}^{3}$ \\
\hline Young modulus & $3750 \mathrm{MPa}$ \\
\hline Melting point & $>164 \mathrm{C}^{\mathbf{o}}$ \\
\hline Elongation & $200 \%$ \\
\hline Spinning oil & $1 \%$ \\
\hline Moisture & Max $3 \%$ \\
\hline Tenacity & $30 \mathrm{Cn} /$ tex \\
\hline Alkali resistance & Excellent \\
\hline Conductivity & Very low \\
\hline
\end{tabular}




\section{F. Silica Fume}

Silica fume commercially known as Mega Add MS(D) from the chemical company Conmix was used as partial replacement of cement throughout this investigation. Tables VII and VIII illustrate its physical and chemical properties. The results show that the used silica fume satisfies the requirements of [16].

TABLE VII. PHYSICAL ANALYSIS OF SILICA FUME

\begin{tabular}{|c|c|c|}
\hline Physical Properties & Results & Requirements of [16] \\
\hline Color & Grey & - \\
\hline Percent retained $45 \mu \mathrm{m}(\mathrm{No} .325)$ & 10 & $\leq 10$ \\
\hline Bulk density $(\mathrm{kg} / \mathrm{m} 3)$ & $\begin{array}{c}500 \text { to } 700 \\
\mathrm{~kg} / \mathrm{m} 3\end{array}$ & \\
\hline Specific surface are $\left(\mathrm{m}^{2} / \mathrm{gm}\right)$ & $>15$ & $>15$ \\
\hline Specific gravity & 2.2 & $>105$ \\
\hline
\end{tabular}

TABLE VIII. CHEMICAL COMPOSITION OF SILICA FUME

\begin{tabular}{|c|c|c|}
\hline Oxides & Oxide content & Requirements of [16] \\
\hline $\mathrm{SiO}_{2}$ & 89 & Min. 85\% \\
\hline $\mathrm{Al}_{2} \mathrm{O}_{3}$ & 0.4 & - \\
\hline $\mathrm{Fe}_{2} \mathrm{O}_{3}$ & 1.2 & - \\
\hline $\mathrm{Mgo}$ & 2.5 & - \\
\hline $\mathrm{CaO}$ & 1.4 & - \\
\hline $\mathrm{So}_{3}$ & 1.0 & - \\
\hline $\mathrm{Na}_{2} \mathrm{O}$ & 1.2 & - \\
\hline
\end{tabular}

\section{G. Limestone Dust}

The limestone dust (Figure 1) was obtained from a limestone quarry in Karbal. It is finely ground in the form of a dust, most of it passing sieve No.100. The chemical composition of the lime dust conforming to [17] is given in Table IX.

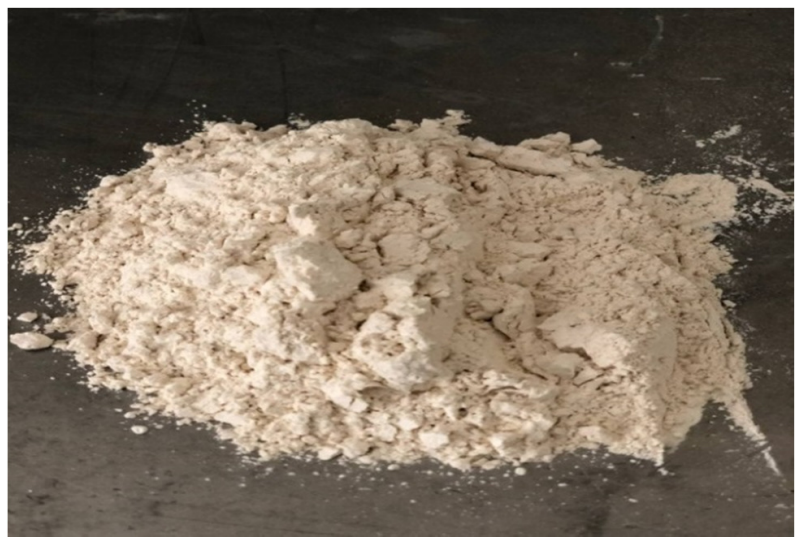

Fig. 1. The limestone dust used in the current research.

TABLE IX. CHEMICAL ANALYSIS OF LIMESTONE DUST

\begin{tabular}{|c|c|c|}
\hline Chemical composition & Constituent(\%) & IQS 807 (\%) \\
\hline Silicon dioxide $\left(\mathrm{SiO}_{2}\right)$ & 5.0 & $5(\max )$ \\
\hline Calcium oxide $(\mathrm{CAO})$ & 52.2 & $80(\max )$ \\
\hline Aluminium oxide $\left(\mathrm{Al}_{2} \mathrm{O}_{3}\right)$ & 0.66 & $5(\max )$ \\
\hline Ferric oxide $\left(\mathrm{Fe}_{2} \mathrm{O}_{3}\right)$ & 0.08 & $5(\max )$ \\
\hline Magnesium oxide $(\mathrm{MgO})$ & 0.51 & $5(\max )$ \\
\hline Sulphur oxide $\left(\mathrm{SO}_{3}\right)$ & 0.0 & - \\
\hline LOI & 41.49 & - \\
\hline
\end{tabular}

\section{H. High-Range Water Reducing Admixture(HRWRA)}

The HRWRA Master Glenium 51 produced by BASF Company, satisfying the ASTM C 494/C 494M-17 [18] was used. The type $\mathrm{F}$ was used as concrete superplasticizer. The technical data of this type of admixture are shown in Table X.

TABLE X. TECHNICAL DESCRIPTION OF THE SUPERPLASTICIZER

\begin{tabular}{|c|c|}
\hline Properties & Technical description \\
\hline Appearance & Viscous liquid. \\
\hline Color & Light brown \\
\hline Density & $1.1 \mathrm{~kg} / \mathrm{lt}$. \\
\hline $\mathrm{pH}$ & 6.6 \\
\hline
\end{tabular}

\section{MIXING, CASTING, AND CURING}

The mixing procedure is important in order to obtain the required workability and homogeneity. Mixing was performed with an electric mixer. The fine aggregates used were in Saturated Surface Dry (SSD) condition. The mixing sequence was the following: the required quantity of dry cement was added to the fine aggregates, the mixing continued for one minute, then the two thirds of the required quantity of water were added to the dry materials. The remaining water and the required quantity of foaming agent were mixed. Drill was used and in the head of the drill it was put the so-called mesh or paddle which rotates at high speed, $14000 \mathrm{rpm}$, with a power supply of $220-240 \mathrm{~V} / 50 \mathrm{~Hz}$. Then the foam agent was added to mix. The mixer was stopped when a good homogeneous mix was produced. Before casting, the mould sides and the base were oiled slightly to prevent mortar sticking to the surfaces. The casting was carried out to two layers. Each layer was compacted by using a large vibrating table. The specimens were left under polyethylene sheets in the laboratory for one day after casting, then they were removed from the molds and kept in closed polyethylene bags for 7,28 , and 90 days until testing time.

TABLE XI. MIX SYMBOLS

\begin{tabular}{|c|c|c|}
\hline Symbols & Type & Content \\
\hline MR & Cube & Mortar + foam agent + silica fume+ HRWRA \\
\hline ML1 & Cube & $\begin{array}{c}\text { Mortar + foam agent }+ \text { silica fume+ HRWRA + lime } \\
\text { dust } 10 \%\end{array}$ \\
\hline ML2 & Cube & $\begin{array}{c}\text { Mortar + foam agent }+ \text { silica fume+ HRWRA + lime } \\
\text { dust } 14 \%\end{array}$ \\
\hline ML3 & Cube & $\begin{array}{c}\text { Mortar + foam agent }+ \text { silica fume+ HRWRA + lime } \\
\text { dust } 18 \%\end{array}$ \\
\hline MF 1 & Prism & $\begin{array}{c}\text { Mortar + foam agent }+ \text { silica fume + HRWRA + lime } \\
\text { dust } 14 \%+\text { polypropylene fiber } 1 \%\end{array}$ \\
\hline MF2 & Prism & $\begin{array}{c}\text { Mortar + foam agent }+ \text { silica fume + HRWRA + lime } \\
\text { dust } 14 \%+\text { polypropylene fibe } 1.5 \%\end{array}$ \\
\hline MF3 & Prism & $\begin{array}{c}\text { Mortar + foam agent }+ \text { silica fume }+ \text { HRWRA + lime } \\
\text { dust } 14 \%+\text { polypropylene fiber } 2 \%\end{array}$ \\
\hline MF4 & Cylinder & $\begin{array}{c}\text { Mortar + foam agent }+ \text { silica fume }+ \text { HRWRA + lime } \\
\text { dust } 14 \%+\text { polypropylene fiber } 1 \%\end{array}$ \\
\hline
\end{tabular}

\section{A. Mix Proportions}

Several mixes were tried in order to find the best mixing of cement to sand, and several ratios were used $(1: 2.25,1: 2,1: 3,1: 1.5,1: 2.5)$. The optimal ratio of $1: 2$ was used. Experimental mixtures were then made by adding different amounts of foam agent to the water allocated to them $(1,3$, and 
$5 \mathrm{ml}$ ) where it was found that adding $3 \mathrm{ml}$ to the water gives the required consistency of the mortar. A reference mixture was made as described in Table XII, three limestone dust ratios $(10 \%, 14 \%$, and $18 \%)$ were used. The best replacement rate of the weight of cement was found to be $14 \%$. This percentage was used in a mixture in which three different ratios of polypropylene fiber $(1 \%, 1.5 \%, 2 \%)$ were used. It was found that best fiber percentage was (1\%). 10\% silica fume was used as a partial replacement of cement and $1 \%$ of HRWRA.

TABLE XII. DETAILS OF CONCRETE MIXES

\begin{tabular}{|c|c|c|c|c|c|c|c|c|}
\hline Mixes & $\begin{array}{c}\text { Cement } \\
\left(\mathbf{K g} / \mathbf{m}^{\mathbf{3}}\right)\end{array}$ & $\begin{array}{c}\text { Sand } \\
\left(\mathbf{K g} / \mathbf{m}^{\mathbf{3}}\right)\end{array}$ & $\mathbf{w} / \mathbf{b}$ & $\begin{array}{c}\text { Silica } \\
\mathbf{f u m e} \\
\mathbf{( g m})\end{array}$ & $\begin{array}{c}\text { Foam } \\
\text { agent } \\
(\mathbf{m l})\end{array}$ & $\begin{array}{c}\text { HRWRA } \\
(\mathbf{m l})\end{array}$ & $\begin{array}{c}\text { Fiber } \\
(\mathbf{g m})\end{array}$ & $\begin{array}{c}\text { Lime } \\
\mathbf{d u s t} \\
\mathbf{( g m})\end{array}$ \\
\hline MR & 300 & 600 & 0.4 & 30 & 3 & 1.5 & - & - \\
\hline ML1 & 300 & 600 & 0.4 & 30 & 3 & 1.5 & - & 30 \\
\hline ML2 & 300 & 600 & 0.4 & 30 & 3 & 1.5 & - & 42 \\
\hline ML3 & 300 & 600 & 0.4 & 30 & 3 & 1.5 & - & 54 \\
\hline MF1 & 300 & 600 & 0.4 & 30 & 3 & 1.5 & 17 & 42 \\
\hline MF2 & 300 & 600 & 0.4 & 30 & 3 & 1.5 & 26 & 42 \\
\hline MF3 & 300 & 600 & 0.4 & 30 & 3 & 1.5 & 34 & 42 \\
\hline MF4 & 300 & 600 & 0.4 & 30 & 3 & 1.5 & 17 & 42 \\
\hline
\end{tabular}

\section{RESULTS AND DISCUSSION}

\section{A. Determination of the Consistency of Mortar (Flow Test)}

The amount of water required for standard consistency of plain mortar or foamed mortar was determined by the flow test. The flow table was prepared according to [19]. The amount of mixing water was sufficient to produce a flow of $110 \pm 5 \mathrm{~mm}$ expressed as a percentage of the original base diameter of the flow mould. The required amounts of water for standard consistency of mortars, expressed in terms of w/c ratio, are shown in Table XIII.

TABLE XIII. DETAILS OF THE MORTAR MIXES WHEN USIN G 1:2 MIX

\begin{tabular}{|c|c|c|}
\hline Foaming Agent (ml) & w/c & Flow 110 $\pm \mathbf{5 m m}$ \\
\hline 1 & 0.4 & 106 \\
\hline 3 & 0.4 & 112 \\
\hline 5 & 0.4 & 117 \\
\hline
\end{tabular}

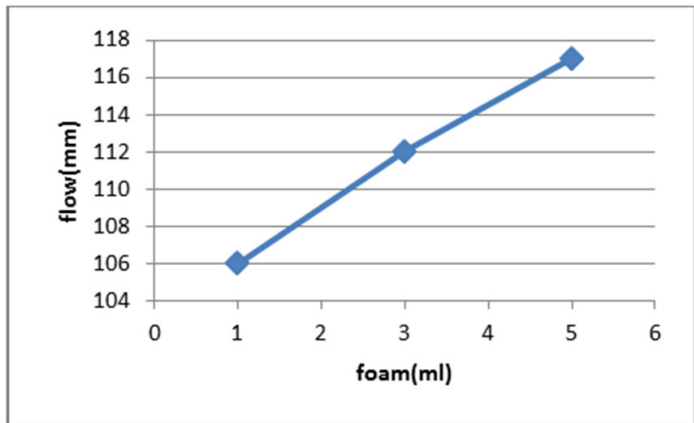

Fig. 2. The relationship between foam and flow.

\section{B. Compressive Strength Test}

This test was conducted on $50 \times 50 \times 50 \mathrm{~mm}$ cubes using an electrical testing machine with a capacity of $2000 \mathrm{KN}$ at fixed load according to [20] .The average of three cubes was recorded for each test conducted at ages of 7, 28, and 90 days as shown in Table XIV.

TABLE XIV. COMPRESSIVE STRENGTH RESULTS

\begin{tabular}{|c|c|c|c|}
\hline \multirow{3}{*}{ Mixes } & \multicolumn{3}{|c|}{ Compressive Strength (MPa) } \\
\cline { 2 - 4 } & $\mathbf{3}$ & $\mathbf{2 8}$ & $\mathbf{9 0}$ \\
\cline { 2 - 4 } & $\mathbf{7}$ & 15.77 & 20.32 \\
\hline MR & 10.45 & 12.32 & 19.93 \\
\hline ML1 & 8.95 & 20.86 & 25.58 \\
\hline ML2 & 10.73 & 12.71 & 17.14 \\
\hline ML3 & 7.41 & 12. \\
\hline
\end{tabular}

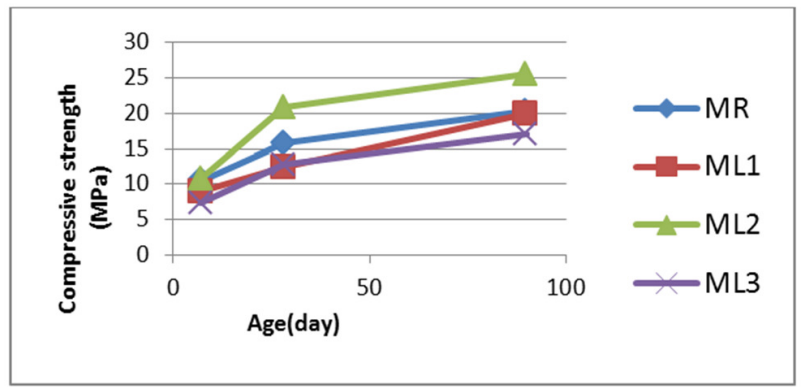

Fig. 3. Compressive strength at 7, 28, and 90 days.

\section{Dry Density Test}

Dry density was determined from the dried weight $\left(105^{\circ} \mathrm{C}\right.$ for 24 hours) and the measured volume by a ruler. Three cubes were measured in each tested sample. The density was found by weighting the specimens and dividing the weight by their measured volume. The dry density was tested at 7,28 , and 90 days as shown in Table XV.

TABLE XV. DRY DENSITY RESULTS

\begin{tabular}{|c|c|c|c|}
\hline \multirow{2}{*}{ Mixes } & \multicolumn{3}{|c|}{ Dry density $\left(\mathbf{k g} / \mathbf{m}^{\mathbf{3}}\right)$} \\
\cline { 2 - 4 } & $\mathbf{7}$ & $\mathbf{2 8}$ & $\mathbf{9 0}$ \\
\cline { 2 - 4 } & 1484 & 1623 & 1730 \\
\hline MR & 1478 & 1601 & 1679 \\
\hline ML1 & 1672 & 1722 \\
\hline ML2 & 1460 & 1572 \\
\hline ML3 & 1354 & 1429 & 1620 \\
\hline
\end{tabular}

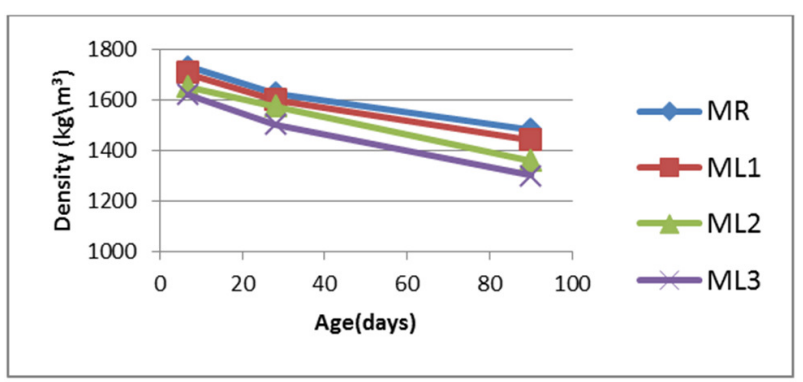

Fig. 4. Density-age relationship.

\section{Splitting Tensile Strength Test}

Splitting tensile strength test was performed according to [21] in which $100 \times 200 \mathrm{~mm}$ cylindrical specimens were used. They were tested using an electrical testing machine with a capacity of $2000 \mathrm{KN}$. This test was conducted at 7, 28, and 90 days as shown in Table XVI. 
TABLE XVI. SPLITTING TENSILE STRENGTH RESULTS

\begin{tabular}{|c|c|c|c|}
\hline \multirow{2}{*}{ Mix } & \multicolumn{3}{|c|}{ Splitting tensile strength (MPa) } \\
\cline { 2 - 4 } & \multicolumn{3}{|c|}{ Age (days) } \\
\hline \multirow{2}{*}{ ML2 } & 7 & 28 & 90 \\
\cline { 2 - 4 } & 0.82 & 1.65 & 2.04 \\
\hline ML4 & 1.01 & 1.89 & 2.21 \\
\hline
\end{tabular}

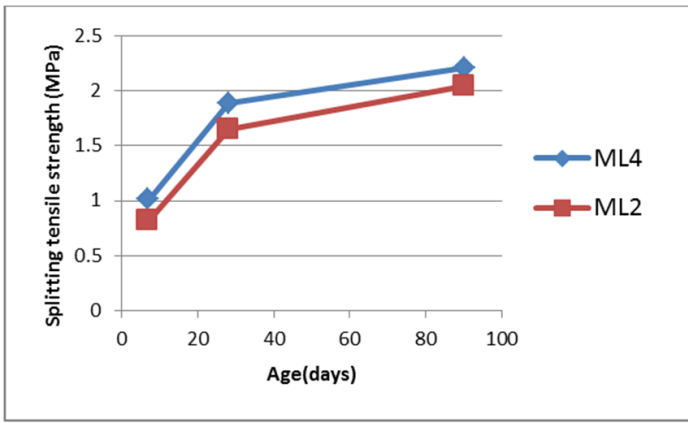

Fig. 5. Splitting tensile strength at 7, 28, and 90 days.

\section{E. Flexural Strength Test}

The flexural strength was determined according to [22] by using the center point method. The prism-shaped specimens with dimensions of $70 \times 70 \times 380 \mathrm{~mm}$ were simply supported with $300 \mathrm{~mm}$ span and were tested at the age of 7, 28, and 90 days as shown in Table XVII.

TABLE XVII. FLEXURAL STRENGTH RESULTS

\begin{tabular}{|c|c|c|c|}
\hline \multirow{2}{*}{ Mix } & \multicolumn{3}{|c|}{ Flexural Strength(MPa) } \\
\cline { 2 - 4 } & \multicolumn{3}{|c|}{ Age (days) } \\
\cline { 2 - 4 } & $\mathbf{7}$ & $\mathbf{2 8}$ & $\mathbf{9 0}$ \\
\hline ML2 & 1.6 & 2.45 & 2.94 \\
\hline MF1 & 3.1 & 3.8 & 4.77 \\
\hline MF2 & 2.33 & 2.7 & 3.69 \\
\hline MF3 & 1.75 & 2.34 & 2.83 \\
\hline
\end{tabular}

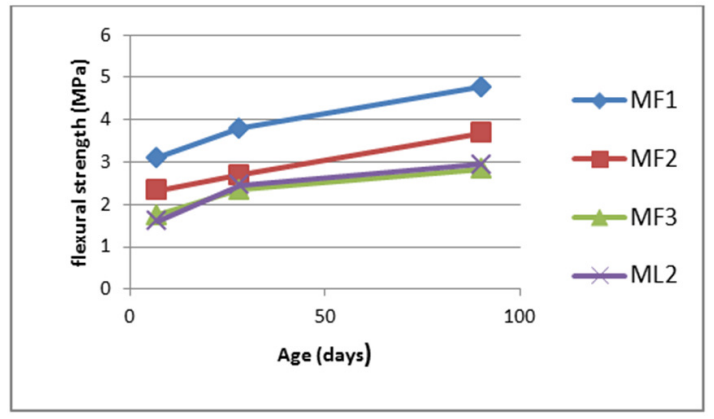

Fig. 6. Flexural strength at 7,28 , and 90 days.

\section{V. CONCLUSION}

Based on the results obtained from the experimental investigation, the following conclusions can be drawn:

- The water requirement for LWC is decreased as the percentage of foaming agent increases and the maximum decrease in water for all concrete mixes was 0.4 as a percentage of cement weight.

- LWC with $3 \mathrm{ml}$ foam agent gave better results of density and compressive strength.
- Compressive strength, flexural strength, and splitting tensile strength of LWC with limestone dust is slightly lower than those of normal concrete at all ages.

- The added foam leads to an increase in the flow. Three amounts of foam were added $(1,3,5 \mathrm{ml})$ and the flow rate was $106,112,117 \mathrm{~mm}$ respectively. Three percentages of foam $(10 \%, 14 \%$, and $16 \%)$ were added to concrete as partial replacement of cement to produce sustainable LWC.

- Flexural strength and splitting tensile strength of LWC with $1 \%$ polypropylene fiber are higher than those of LWC without fiber at all ages.

- The best results were for specimens of LWC having a combination of polypropylene fibers $(1 \%)$ and limestone dust $(14 \%)$ due to the further physical effect of micro steel fibers in addition to the effect of limestone dust.

The results of this research confirm that we can use limestone dust to produce green LWC and enhance its properties with polypropylene fibers.

\section{REFERENCES}

[1] F. S. Fulton, Concrete Technology, 7th ed. The Portland Cement Institute, 1994.

[2] M. S. Shetty and A. K. jain, "Chapter 12," in Concrete Technology: Theory and Practice, 8th ed., S. Chand Publishing, 2019.

[3] N. Bheel, A. W. Abro, I. A. Shar, A. A. Dayo, S. Shaikh, and Z. H. Shaikh, "Use of Rice Husk Ash as Cementitious Material in Concrete," Engineering, Technology \& Applied Science Research, vol. 9, no. 3, pp. 4209-4212, Jun. 2019, https://doi.org/10.48084/etasr.2746.

[4] N. Bheel, R. A. Abbasi, S. Sohu, S. A. Abbasi, A. W. Abro, and Z. H. Shaikh, "Effect of Tile Powder Used as a Cementitious Material on the Mechanical Properties of Concrete," Engineering, Technology \& Applied Science Research, vol. 9, no. 5, pp. 4596-4599, Oct. 2019, https://doi.org/10.48084/etasr.2994.

[5] B. H. A. Bakar, A. T. Noaman, and H. M. Akil, "Cumulative Effect of Crumb Rubber and Steel Fiber on the Flexural Toughness of Concrete," Engineering, Technology \& Applied Science Research, vol. 7, no. 1, pp. 1345-1352, Feb. 2017, https://doi.org/10.48084/etasr.854.

[6] C09 Committee, "ASTM C321-17: Specification for Lightweight Aggregates for Insulating Concrete," ASTM International. https://doi.org/10.1520/C0332-17.

[7] C09 Committee, "ASTM C331-17: Specification for Lightweight Aggregates for Concrete Masonry Units," ASTM International. https://doi.org/10.1520/C0331_C0331M-17.

[8] C09 Committee, "ASTM C330/C330M - 17a: Specification for Lightweight Aggregates for Structural Concrete," ASTM International. https://doi.org/10.1520/C0330_C0330M-17A.

[9] H. J. Goodman, "Low-density concrete," in Fulton's Concrete Technology, 7th ed., B. J. Addis, Ed. Portland Cement Institute, 1994, pp. 281-285.

[10] N. M. Fawzi, "Properties of lightweight Concrete with a view to thermal insulation and acoustic impedance," M.S. thesis, University of Baghdad, Baghdad, Iraq, 1997.

[11] N. Aljalawi, "Behavior of polypropylene fiber reinforced concrete under impact loads and explosive," Journal of the College of Engineering of Baghdad University, vol. 11, no. 3, pp. 59-68, Sep. 2005.

[12] Iraqi Standard No. 5: Portland Cement. Baghdad, Iraq: Central Organizationfor Standardization and Quality Control, 2019.

[13] Iraqi Specification, No. 45 Aggregate from Natural Sources for Concrete and Construction. Baghdad, Iraq, 1984.

[14] C09 Committee, "ASTM C796 - 97: Standard Test Method for Foaming Agents for Use in Producing Cellular Concrete Using Preformed Foam," ASTM International. https://doi.org/10.1520/C0796-97. 
[15] Iraqi Specification, No .1703: Water used in concrete. Baghdad, Iraq: Central Organization for Standardization and Quality Control, 1992.

[16] C09 Committee, "ASTM C1240 - 03a: Specification for Silica Fume Used in Cementitious Mixtures," ASTM International. https://doi.org/ 10.1520/C1240-03A

[17] Iraqi Standard No. 807: Lime used in construction and in the production of building materials. Baghdad, Iraq: Central Organization for Standardization and Quality Control, 1982.

[18] C09 Committee, "ASTM C494 / C494M - 17: Standard Specification for Chemical Admixtures for Concrete," ASTM International. https://doi.org/10.1520/C0494_C0494M-17.

[19] C01 Committee, "ASTM C230 / C230M - 21: Standard Specification for Flow Table for Use in Tests of Hydraulic Cement," ASTM International. https://doi.org/10.1520/C0230_C0230M-21.

[20] C01 Committee, "ASTM C109 / C109M - 16a: Standard Test Method for Compressive Strength of Hydraulic Cement Mortars (Using 2-in. or [50-mm] Cube Specimens)," ASTM International. https://doi.org/ 10.1520/C0109_C0109M-16A.

[21] C09 Committee, "ASTM C496 / C496M - 11: Standard Test Method for Splitting Tensile Strength of Cylindrical Concrete Specimens," ASTM International. https://doi.org/10.1520/C0496_C0496M-11.

[22] C09 Committee, "ASTM C293 / C293M - 16: Standard Test Method for Flexural Strength of Concrete (Using Simple Beam With Center-Point Loading)," ASTM International. https://doi.org/10.1520/ C0293_C0293M-16. 